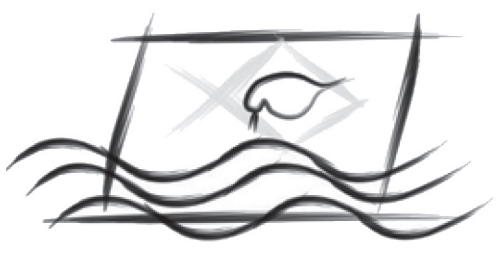

J. Braz. Soc. Ecotoxicol., v. 5, n. 1, 2010, 33-39

doi: 10.5132/jbse.2010.01.006

ECOTOX - Brazil

\title{
Aerobic Reactors for Biotreatment of Polluted Waters and Synthetic Effluents Containing 3-Chlorobenzoic Acid
}

\author{
A. Gallego ${ }^{1 *}$, A. Rossen ${ }^{1}$, V. Gemini ${ }^{1,2}$, M. S. Fortunato ${ }^{1}$, S. Rossi ${ }^{1}$, E. Planes ${ }^{2} \&$ S. Korol ${ }^{1}$ \\ ${ }^{1}$ Cátedra de Higiene y Sanidad, Facultad de Farmacia y Bioquímica, Universidad de Buenos Aires, \\ Junín 956, $4^{\circ}$ Piso, CP 1113, Buenos Aires, Argentina \\ ${ }_{2}^{2}$ Instituto Nacional de Tecnología Industrial, Av. Gral Paz 5445, CC 157, CP 1650, San Martín - Buenos Aires, Argentina
}

(Received May 2, 2008; Accepted August 14, 2009)

\begin{abstract}
The degradation of 3-chlorobenzoic acid in polluted waters and synthetic effluents by a previously isolated indigenous strain of Pseudomonas putida was studied. Batch biodegradation assays were performed using a $2 \mathrm{~L}$ microfermentor at $28^{\circ} \mathrm{C}$ with agitation. To simulate polluted water, $100 \mathrm{mg} . \mathrm{L}^{-1}$ of 3-chlorobenzoic acid were added to surface river water. Continuous-flow assays were performed in an aerobic up-flow fixed-bed reactor constructed from PVC employing hollow PVC cylinders as support material. Synthetic wastewater was prepared by dissolving 3-chlorobenzoic acid in non-sterile groundwater. Biodegradation was evaluated by spectrophotometry, chloride release, gas chromatography and microbial growth. In batch experiments the indigenous strain of Pseudomonas putida degrades $100 \mathrm{mg} . \mathrm{L}^{-1}$ of 3-chlorobenzoic acid in 28 hours with a removal efficiency of 92.2 and $87.2 \%$, expressed as compound and chemical oxygen demand removal, respectively. In the continuous-flow reactor the removal of an average influent concentration of $98.6 \mathrm{mg} . \mathrm{L}^{-1}$ reached $91.7 \%$ of compound and $88.9 \%$ of COD removal. The process efficiency remained approximately constant despite changes in the influent flow, compound concentration and temperature. The absence of metabolites was determined by gas chromatography performed at the end of the batch process and at the effluent of the continuous reactor. The ability of the isolated indigenous strain to degrade 3-chlorobenzoic acid in both batch and continuous reactors represents a promising feature to improve the treatment of effluents.
\end{abstract}

Keywords: 3-chlorobenzoic acid, biodegradation, indigenous strain, Pseudomonas putida, up-flow aerobic reactor.

\section{RESUMO}

\section{Reatores Aeróbicos para o Biotratamento de Águas Poluídas e Efluentes Sintéticos Contendo Ácido 3-Clorobenzóico}

Foi estudada a degradação do ácido 3-clorobenzóico em águas poluídas e efluentes sintéticos por uma cepa nativa previamente isolada de Pseudomonas putida. Ensaios de biodegradação de lotes foram realizados usando um microfermentador de $2 \mathrm{~L}$ a $28{ }^{\circ} \mathrm{C}$ sob agitação. Para simular água poluída, $100 \mathrm{mg} . \mathrm{L}^{-1}$ de ácido 3-clorobenzóico foram adicionados a água superficial de rio. Foram realizados ensaios de fluxo contínuo num reator aeróbico de fluxo ascendente de leito fixo construído em PVC, utilizando cilindros de PVC como material de suporte. Água sintética residuária foi preparada dissolvendo ácido 3-clorobenzóico em água subterrânea não estéril. A biodegradação foi avaliada por espectrofotometria, liberação de cloreto, cromatografia gasosa e crescimento microbiano. Nos experimentos em lote, a cepa nativa de Pseudomonas putida degrada $100 \mathrm{mg} . \mathrm{L}^{-1} \mathrm{de}$ ácido 3-clorobenzóico em 28 horas com uma eficiência de remoção de 92,2 e 87,2\%, expressada como remoção de composto e demanda de oxigênio químico, respectivamente. No reator de fluxo contínuo, a remoção de uma concentração média de afluente de 98,6 mg.L. $\mathrm{L}^{-1}$ atingiu $91,7 \%$ do composto e $88,9 \%$ da remoção de COD. A eficiência do processo permaneceu aproximadamente constante apesar das mudanças de fluxo, concentração do composto e temperatura. A ausência de metabólitos foi determinada por cromatografia gasosa realizada no final do processo em lote e no efluente do reator continuo. A capacidade da cepa nativa para degradar o ácido 3-clorobenzóico em ambos os lotes e reatores contínuos representa uma função promissora para melhorar o tratamento de efluentes.

Palavras-chave: ácido 3-clorobenzóico, biodegradação, cepa nativa, Pseudomonas putida, reator aeróbico ascendente.

* Corresponding author: Alfredo Gallego, e-mail: agallego@ffyb.uba.ar 


\section{INTRODUCTION}

The ever-increasing industrial use of new synthetic organic compounds has resulted in a build-up of xenobiotic compounds in the environment. They are often recalcitrant to biodegradation, thus persisting in the ecosystems and augmenting the exposition risk to organisms. Chlorobenzoates are examples of such compounds. 3-chlorobenzoic acid, specifically, is employed as raw material in the formulation of dyes, pharmaceuticals, fungicides and as a preserving agent for adhesives and paints. Like other chlorobenzoates it can originate both as a dead-end product from the cometabolism of PCBs and chlorotoluenes (Baggi; Zangrossi, 2001) and in water chlorination processes. The result of its widespread use is that it can be found as a contaminant in industrial effluents, rivers and groundwater, thus persisting as a toxic compound in the environment for long periods. A half-life of 38, 75 and 340 days was estimated for the compound in water, soil and sediments, respectively, using EPA's PBT profiler (EPA, 2006). Despite this, several microorganisms able to degrade the compound have been reported (Hernández et al., 1991; Saini et al., 1998; Fulthorpe et al., 1998; Pavlú et al., 1999; Krooneman et al., 2000; Song et al., 2000).

Studies usually focused on the degradation of the compound in synthetic culture media; however, it is of great significance the assessing of the ability of the bacterium to carry out the process in a polluted environment. It is important that these degradation studies should focus on realistic bioreactor operating conditions (Pallerla; Cambers, 1998), which will allow the transfer of results.

In a previous work, the isolation of an indigenous strain of Pseudomonas putida from a polluted Buenos Aires River was reported (Gallego et al., 2005). The bacterial strain was capable of degrading up to $1000 \mathrm{mg} . \mathrm{L}^{-1}$ of 3-chlorobenzoic acid. It was also demonstrated that the biodegradation process was not affected by the different factors assayed, such as initial concentration, $\mathrm{pH}$ and inoculum density, nor was the simultaneous presence of readily biodegradable or related toxic compounds. The purpose of the present investigation was to study the degradation of 3-chlorobenzoic acid in polluted waters and synthetic effluents by the isolated indigenous strain in both batch and continuous flow fixed-bed aerobic reactors.

\section{MATERIAL AND METHODS}

An indigenous bacterial strain was employed in this study. The isolation from a polluted Buenos Aires River and its identification were described in a previous work (Gallego et al., 2005). The strain was identified as Pseudomonas putida using the API system and confirmed by obtaining the partial 16S rRNA gene sequence. Pseudomonas putida was able to grow and degrade $100 \mathrm{mg} . \mathrm{L}^{-1}$ of 3-chlorobenzoic acid in minimal medium in a pH range between 6 and 9. The biodegradation was not affected by the absence of adaptation to the compound or the decrease of one order in the initial inoculum of $1 \times 10^{6} \mathrm{CFU} . \mathrm{mL}^{-1}$. The simultaneous presence readily metabolizing subtrates such as glucose $\left(100 \mathrm{mg} . \mathrm{L}^{-1}\right)$ or sodium acetate $\left(100 \mathrm{mg} . \mathrm{L}^{-1}\right)$ in the culture medium did not affect the efficiency of the biodegradation process. Neither did the presence of toxic-related compounds, like phenol, o-cresol, m-cresol, p-cresol, 2-chlorophenol, 3-chlorophenol, 4-chlorophenol, 2,4-dichlorophenol, 2,4,6-trichlorophenol or 4-chlorobenzoic acid in concentrations of $10 \mathrm{mg} . \mathrm{L}^{-1}$, inhibit the degradation of 3-chlorobenzoic acid (100 mg.L-1 $)$.

The bacteria were adapted by inoculation in synthetic minimal medium (Korol et al., 1989) supplemented with $100 \mathrm{mg} . \mathrm{L}^{-1}$ of 3-chlorobenzoic acid as carbon source, and incubated in a rotatory shaker at $28{ }^{\circ} \mathrm{C}$ overnight (stock culture).

Biodegradation assays in batch reactor were performed in a New Brunswick Multigen TA microfermentor, aerobically operated at $28{ }^{\circ} \mathrm{C}$ with an effective volume of $1,250 \mathrm{~mL}$. To simulate polluted water $100 \mathrm{mg} . \mathrm{L}^{-1}$ of 3 -chlorobenzoic acid were added to surface river water. During incubation, $10 \mathrm{~mL}$ samples were removed from the system at appropriate intervals in order to determine the amount of remaining 3-chlorobenzoic acid and evaluate microbial growth.

Continuous-flow biodegradation assays were performed in an aerobic up-flow fixed-bed reactor constructed with PVC (50 $\times 15 \mathrm{~cm}$ internal diameter, $7.7 \mathrm{~L}$ effective volume). The column was filled with hollow cylinders (approximately $15 \times 15 \mathrm{~mm}$ in diameter) cut from a PVC conduit used in electrical wiring and employed here as a support for bacterial biofilm immobilization. A diagram to scale of the reactor is shown in Figure 1. Non sterile air was supplied by an aeration pump from the bottom of the column at a flow rate of $1 \mathrm{~L} \cdot \mathrm{min}^{-1}$. The reactor was operated under environmental non-sterile conditions at room temperature. It was fed continuously with synthetic wastewater prepared by using 3-chlorobenzoic acid and a farming fertilizer (BASF) free from chloride, ratio of N:P:K 10:2:6. Initial concentration of the compound was $50 \mathrm{mg} . \mathrm{L}^{-1}$, later increased to $100 \mathrm{mg} . \mathrm{L}^{-1}$. The synthetic wastewater flows through the reactor by a hydrostatic pressure gap, without energy consumption. The influent flow rate was between 2 and 2.5 L.day ${ }^{-1}$ to give an estimated residence time of three days. Non-sterilized groundwater was employed as dilution water. Before start-up, the reactor was inoculated with Pseudomonas putida and operated in batch mode for one month to allow biofilm formation on the support. The reactor was kept in operation for six months.

To estimate the absence of other degrading microorganisms and the abiotic loss of the compound controls in similar batch and continuous reactors, without inoculation, were carried out. The batch reactor assay was conducted for three days whereas the continuous reactor was operated for one month.

To evaluate the bacterial biofilm, $10 \mathrm{~g}$ of the support material in $100 \mathrm{~mL}$ of a sterile saline solution were suspended and subjected to vortex agitation for 4 minutes. The counting and identification of the removed bacteria from the support were then executed. To test their degradation capacity, biodegradation assays with bacterial isolates were carried out in minimal medium containing $50 \mathrm{mg} . \mathrm{L}^{-1}$ of 3-chlorobenzoic acid Scanning electronic microscopy (Philips XI30) was employed in order to observe the bacterial cells on the PVC cylinder in the reactor. 


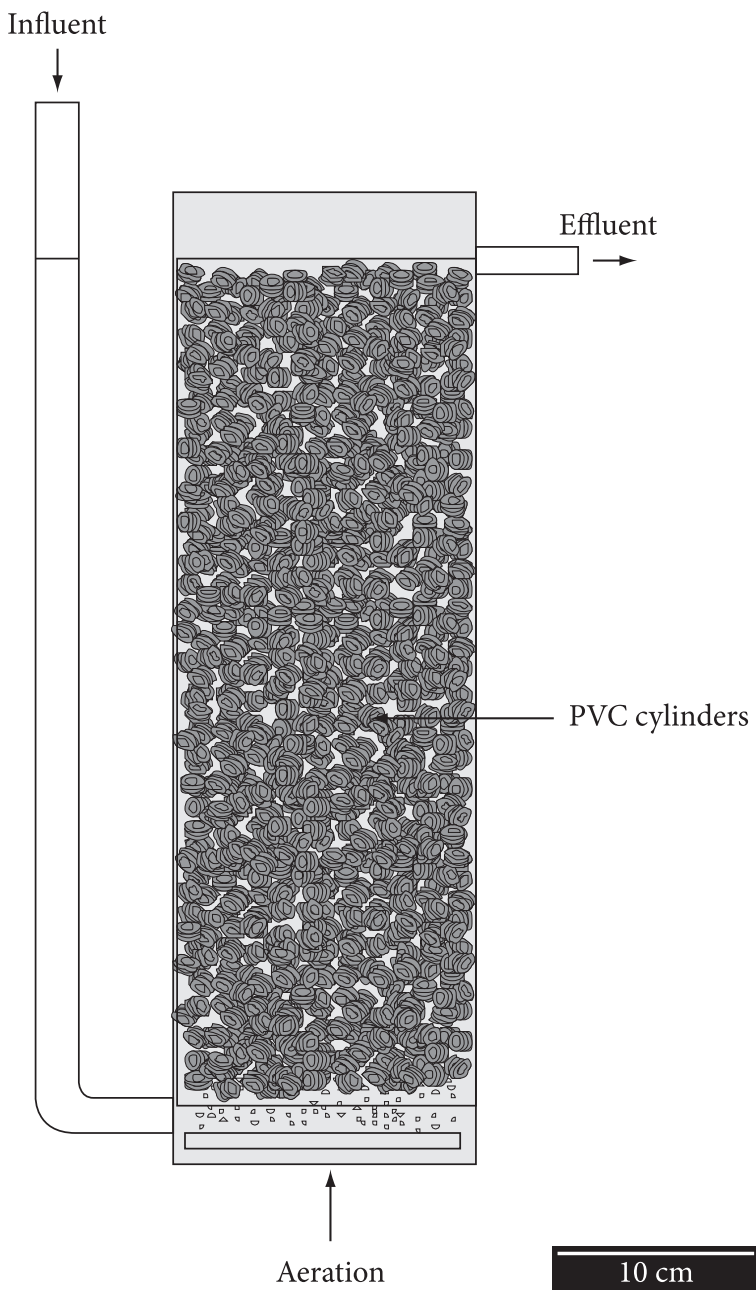

Figure 1 - Experimental up-flow aerobic fixed bed reactor.

3-chlorobenzoic acid was of analytical grade and purchased from Flucka (Buchs, Switzerland). All the other chemicals were of analytical reagent grade and purchased from Mallinckrodt Chemical Co. (St. Louis, USA), and Merck (Darmstadt, Germany). 3-chlorobenzoic acid was prepared aseptically by dissolving the necessary amount in sterile $0.1 \mathrm{~N} \mathrm{NaOH}$.

To determine the amount of remaining 3-chlorobenzoic acid, bacterial cells were separated by centrifugation, and the filtered supernatant fluid was submitted to spectrophotometrical analysis (Metrolab UV 1700 Spectrophotometer); the absorbance in $0.1 \mathrm{~N} \mathrm{NaOH}$ was measured at $230 \mathrm{~nm}$. A standard curve with 3-chlorobenzoic acid at different concentration was run simultaneously. Chemical oxygen demand (COD) and chloride were measured in samples taken at the beginning and at the end of the batch process, and at the influent and effluent of the continuous reactor, according to APHA (2005). Determination of cell viability was performed by spreading sample dilutions on the surface of nutrient agar plates (APHA, 2005).

To assess mineralization, selected samples were analyzed by gas chromatography. The samples at $\mathrm{pH} 4$ were injected without a concentration step. Hewlett-Packard model 6890 gas

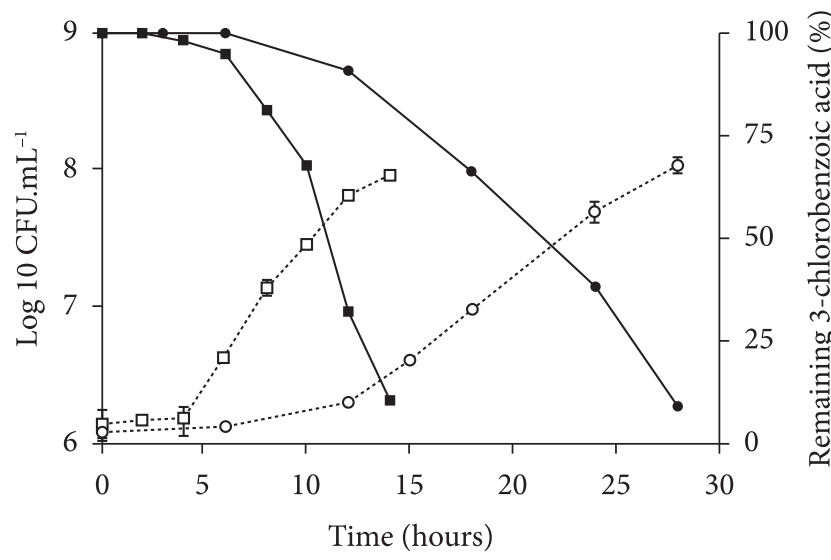

Figure 2 - Batch reactor. Degradation of 3-chlorobenzoic acid by Pseudomonas putida in synthetic minimal medium and polluted waters. Growth kinetics of strain with a concentration of $100 \mathrm{mg} . \mathrm{L}^{-1}$ both in minimal medium (--口--) and polluted waters (--०--). Remaining 3-chlorobenzoic acid in minimal medium (- - )

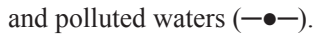

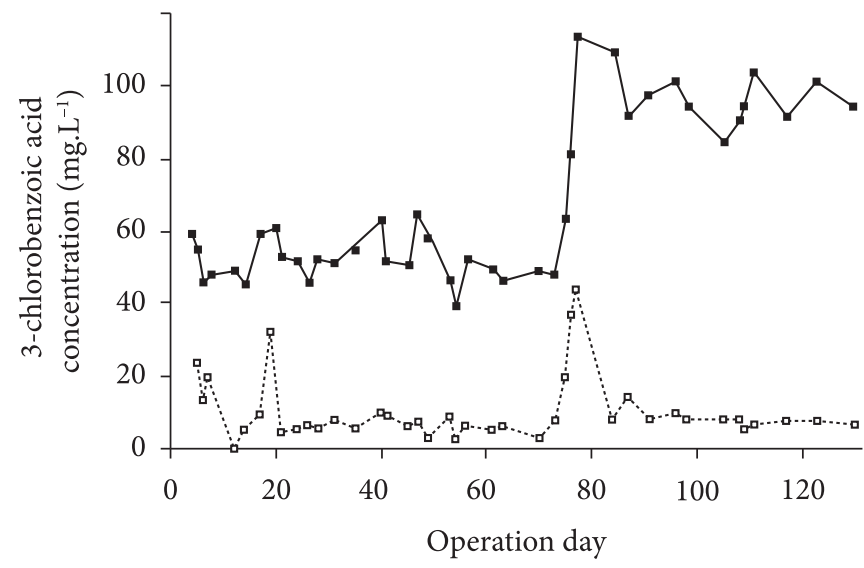

Figure 3 - Degradation of 3-chlorobenzoic acid by Pseudomonas putida in aerobic up-flow fixed bed reactor. 3-chlorobenzoic acid concentration (mg. $\left.\mathrm{L}^{-1}\right)$ in the influent (---) and in the effluent (-- --).

chromatograph equipped with a Model 5972 mass selective detector was used. Separations were obtained using a capillary column (HP-5MS, $30 \mathrm{~m} \times 0.25 \mathrm{~mm}, 0.25 \mathrm{~mm}$ film) with He as carrier gas and a gradient of temperature from 120 to $290{ }^{\circ} \mathrm{C}$, increasing at $15^{\circ} \mathrm{C} \mathrm{min}^{-1}$. Detection was done in SCAN (data not show) and SIM mode.

\section{RESULTS}

The assays carried out in batch reactors with simulated polluted water show that the indigenous strain of Pseudomonas putida was capable of degrading $100 \mathrm{mg} . \mathrm{L}^{-1}$ of 3-chlorobenzoic acid in 28 hours. The specific growth rate $(\mu)$ was 0.22 hours $^{-1}$ and the process efficiency of 92.2 and $87.2 \%$ expressed as compound and chemical oxygen demand removal, respectively (Table 1). Chloride was stoichiometrically released. Figure 2 shows degradation kinetics compared with that obtained in minimal medium with the same concentration of the compound. 
Table 1 - Degradation of 3-chlorobenzoic acid by Pseudomonas putida in batch and continuous reactors.

\begin{tabular}{|c|c|c|c|c|c|c|}
\hline \multirow[t]{2}{*}{ Parameter } & \multicolumn{3}{|c|}{ Batch reactor } & \multicolumn{3}{|c|}{ Fixed-Bed reactor } \\
\hline & Initial & Final & \% Removal & Influent & Effluent & \% Removal \\
\hline 3-Chlorobenzoic acid (mg.L-1 $)$ & 97.4 & 7.6 & 92.2 & 96.4 & 8.0 & 91.7 \\
\hline $\mathrm{COD}\left(\mathrm{mg} \cdot \mathrm{L}^{-1}\right)$ & 234.2 & 30.0 & 87.2 & 205.2 & 22.8 & 88.9 \\
\hline Chloride (mg.L $\mathrm{L}^{-1}$ ) & 34.2 & 54.2 & - & 26.8 & 46.3 & - \\
\hline
\end{tabular}
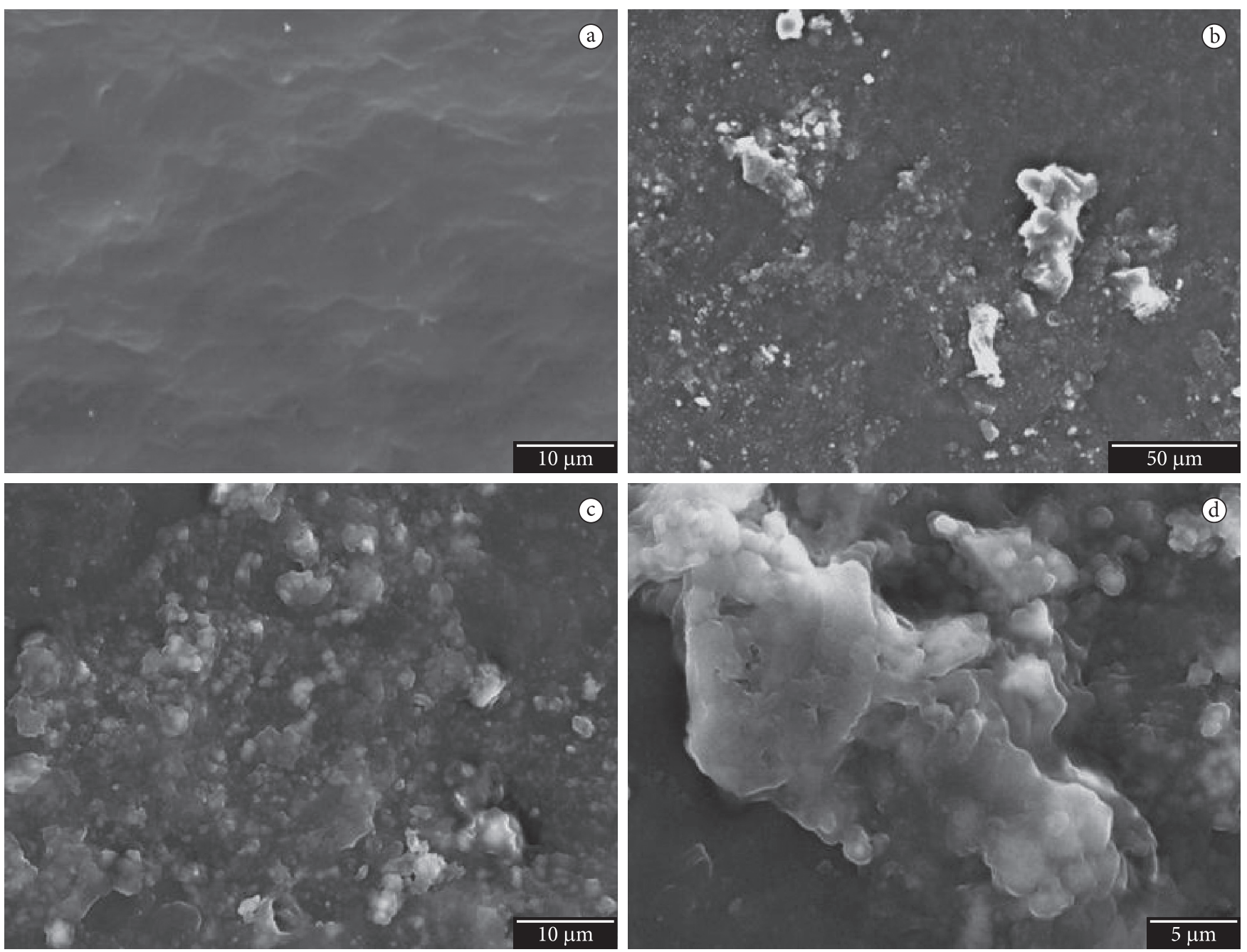

Figure 4 - Scanning electron microscope photomicrographs of PVC cylinders surface:

(a) before inoculation $(1520 \times$ ) and after inoculation (b) $500 \times$ (c) $2000 \times$ (d) $3500 \times$.

Despite the increase in the lag phase and the decrease in the specific growth rate $\left(\mu_{\text {MINIMAL medium }}: 0.41\right.$ hours $\left.^{-1}\right)$, the biodegradation process in polluted water occurred within a time period still suitable for biological treatment and with the same removal efficiency obtained in minimal medium. The results obtained with the batch control reactor show that the remaining concentration of 3-chlorobenzoic acid at the end of the process was $99 \%$ of the initial concentration.

Assays performed in the fixed-bed reactor under operating conditions were initially carried out with an average influent concentration of $51.9 \mathrm{mg} . \mathrm{L}^{-1}$ of 3-chlorobenzoic acid. Compound removal reached $86.5 \%$. Then the influent concentration was increased to an average value of $96.4 \mathrm{mg} . \mathrm{L}^{-1}$ (Figure 3), representing an organic load of 31.3 and $66.6 \mathrm{~g} . \mathrm{m}^{-3}$.day ${ }^{-1}$ expressed in terms of 3-chlorobenzoic acid and COD respectively. With this influent concentration, the 3-chlorobenzoic acid removal efficiency and the COD achieved were of 91.7 and $88.9 \%$ respectively (Table 1). Chloride was also stoichiometrically released in these assays.

The hydraulic residence time was 72 hours. The process efficiency remained approximately constant despite changes in the influent flow, compound concentration and temperature, which fluctuated between 10 and $28^{\circ} \mathrm{C}$. 

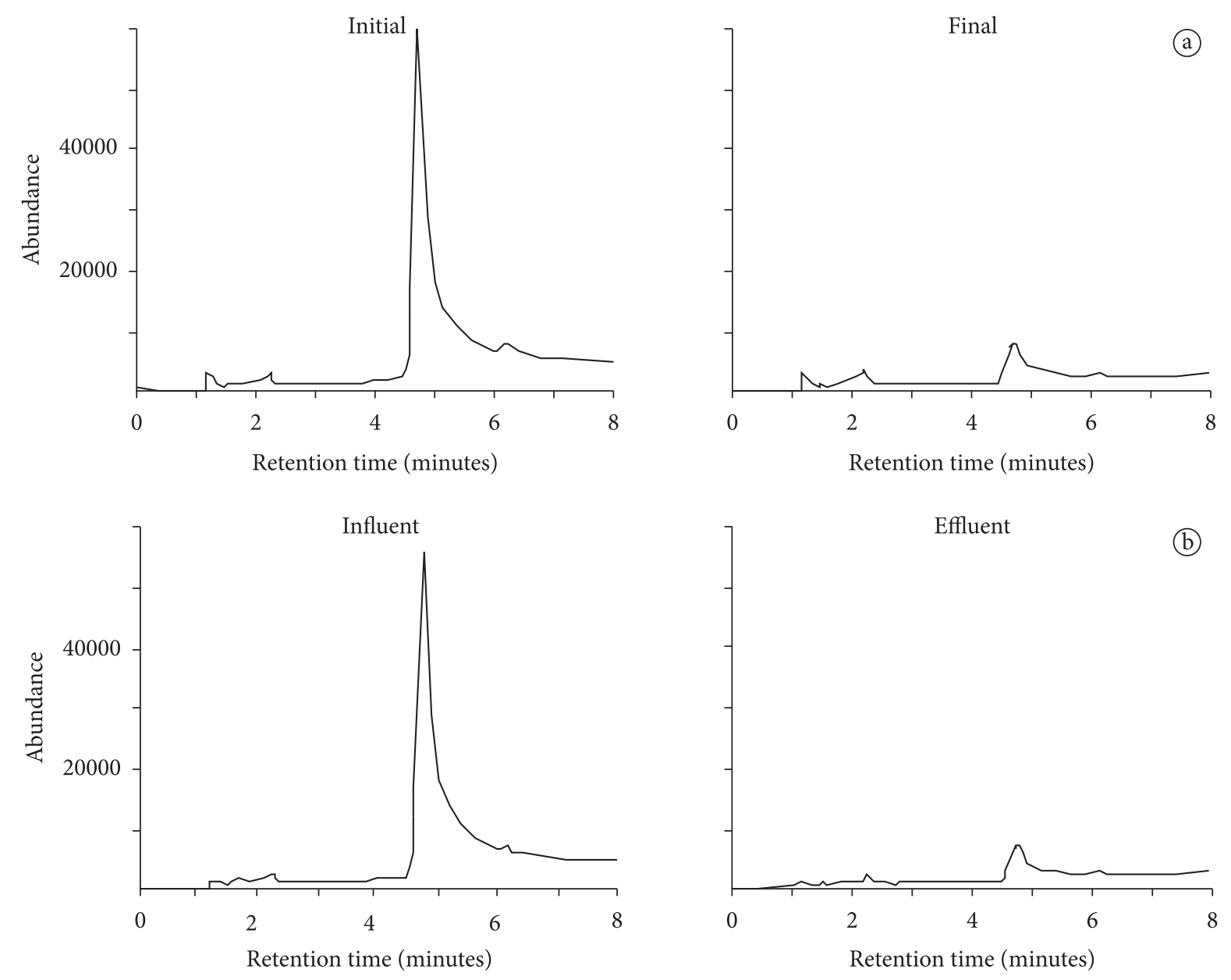

Figure 5- GC MS chromatograms: (a) batch reactor; (b) fixed-bed reactor.

It is noteworthy that the biomass of the degrading microorganism in the reactor remained approximately constant in the aqueous phase, and developed only from initial inocula, so that reinoculation was not necessary. Total bacterial count in the continuous reactor effluent reached $3.0 \times 10^{6} \mathrm{CFU} . \mathrm{mL}^{-1}$. Pseudomonas putida was predominant, although other environmental bacteria were isolated; the laboratory testing under batch conditions that we performed showed that the other environmental bacteria cannot degrade 3-chlorobenzoic acid. The indigenous strain was also predominant in the bacteria removed from the support. Data from the bacteria removed by vortex agitation allowed us to estimate a $1.8 \times 10^{8} \mathrm{CFU} . \mathrm{g}^{-1}$ biomass for the support material. The control assay shows that the remaining concentration of 3-chlorobenzoic acid in the effluent was 99\%, thus, proving the role of the Pseudomonas putida strain in the biodegradation of the compound and the absence of abiotic loss in the system.

Figure 4 shows the scanning electron microscopy of the surface of the PVC cylinders before and after inoculation.

The absence of metabolites was demonstrated by gas chromatography carried out at the end of the batch process and in the fixed-bed reactor effluent (Figure 5).

\section{DISCUSSION}

Although several bacteria able to degrade 3-chlorobenzoic acid have been reported, few studies have focused on the application to polluted environments of the isolated microorganism. Certain bacterial features are critical considering their potential application. A high specific growth rate of the strain has been pointed out as outstanding because it allows the strain to compete with the other microorganisms (Kar et al., 1997). Moreover, the microorganism resistance to high concentrations plays an important role when substrates are toxic. The isolated indigenous strain of Pseudomonas putida showed both these features, and exhibited thus a promising behavior which allowed the performance of assays in polluted waters and synthetic effluents. Chromatography data in SIM and SCAN mode, associated with the decrease in COD values and the absence of UV absorbance demonstrated the mineralization of the compound and the absence of metabolites.

The investigation carried out in surface waters proves the ability of the strain to grow and degrade the compound in a natural environment. The removal efficiency achieved was similar to that obtained in minimal medium at regulated $\mathrm{pH}$ and in the absence of other microorganisms. At the end 
of the assay the indigenous strain of Pseudomonas putida was absolutely predominant. In an uninoculated control the initial river bacterial count was $1.2 \times 10^{5} \mathrm{CFU} . \mathrm{mL}^{-1}$, which decreased to $2.3 \times 10^{3} \mathrm{CFU} \cdot \mathrm{mL}^{-1}$ demonstrating the toxicity of the compound. A fixed-bed continuous reactor was used for the experiments because biofilm processes have been shown to be less sensitive to toxic compounds than suspended sludge processes (Perron; Welander, 2004). A wide variety of materials have been employed for supporting growth in biofilm reactors. Frequently reported support materials include calcium alginate (González et al., 2001), granulated activated carbon (Wilson et al., 1997), polyurethane foam (Hsien; Lin, 2005), or siliceous granular materials such as pumice (Kaşikara Pazarlioğlu; Telefoncu, 2005) or PORAVER ${ }^{\circledR}$ (Sá; Boaventura, 2001). Qureshi et al., (2001) employed hollow PVC cylinders cut from conduit used in electrical wiring in a biofilm reactor for copper adsorption. In a previous work we used the same support material for the treatment of a synthethic effluent containing $o$-cresol, $m$-cresol and $p$-cresol (Gallego et al., 2008). Since the main objective of our work is transferring results to industrial applications, operating and construction costs play an important role in reactor design. Both the use of an inexpensive support material and the passive flow obtained without the use of pumps are desirable for such purposes. The operating of the reactor in batch mode to facilitate start-up was reported elsewhere (Sá; Boaventura, 2001; Quan et al., 2003; Kargi; Ecker, 2005). This objective was reached, since after the start-up of the reactor the compound concentration in the effluent decreased to average minimum values in only ten days of operation. Removal efficiency of 3-chlorobenzoic acid was similar to that obtained in batch reactors in minimal medium. The indigenous strain of Pseudomonas putida was the only 3 -chlorobenzoic acid degrader that was isolated in both the reactor effluent and the support material. Unlike other authors (Fulthorpe; Wyndham, 1991; Springael et al., 2002), who have reported the gene transfer of the degradation capability, no other environmental bacteria capable of degrading the compound were detected when carrying out this work. The laboratory testing under batch conditions that we performed showed that the other environmental bacteria cannot degrade 3 -chlorobenzoic acid.

It is suggested that the ability of the isolated indigenous Pseudomonas putida strain can be exploited to improve the treatment of wastewaters containing 3-chlorobenzoic acid and to bioremediate 3-chlorobenzoic acid-polluted sites. The use of the continuous reactor proposed in this work can be considered as an inexpensive alternative to treat effluents efficiently.

Acknowledgements - We thank the University of Buenos Aires for the grant given for this study supported by the UBACYT Program - Projects B125.- B022

\section{REFERENCES}

APHA, 2005, Standard Methods for the Examination of Water and Wastewater. $21^{\text {th }}$ ed. American Public Health Association,
American Water Works Association, Water Environment Federation, Washington, DC.

BAGGI, G. \& ZANGROSSI, M., 2001, Assessment of the biodegradative potential versus chlorobenzoates as single or mixed compounds in a stable microbial consortium. Ann. Microbiol., 51:179-188.

EPA, 2006, United States Environmental Protection Agency. Office Of Pollution Prevention And Toxics - PBT PROFILER. Available from: $<$ http://pbtprofiler.net>. Acess in: 21 Sept. 2006.

FULTHORPE, R. R. \& WYNDHAM, R. C., 1991, Transfer and expression of the catabolic plasmid pBRC60 in wild bacterial recipients in a freshwater ecosystem. Appl. Environ. Microbiol., 57: 1546-1553.

FULTHORPE, R. R., RHODES, A. N. \& TIEDJE, J. M., 1998, High level of endemicity of 3-chlorobenzoate-degrading soil bacteria. Appl. Environ. Microbiol., 64:1620-1627.

GAllego, A., GEMINI, V., FORTUNATO, M. S., DABAS, P., ROSSI, S., GÓMEZ, C. E., VESCINA, C., PLANES, E. \& KOROL, S., 2008, Degradation and detoxification of cresols in synthetic and industrial wastewater by an indigenous strain of Pseudomonas putida in aerobic reactors. Environ. Toxicol, 23: 664-671. doi:10.1002/tox.20365.

GAllego, A., GEMINI, V., ROSSEN, A., ROSSI, S., FORTUNATO, M. S., TRIPODI, V., CORACH, D., PLANES, E. \& KOROL, S., 2005, Biodegradation and detoxification of 3-chlorobenzoate: effect of additional carbon sources and $\mathrm{pH}$. In: Abstract of the $13^{\text {th }}$ International Biodeterioration and Biodegradation Symposium. Madrid, Spain, p. 4-9.

GONZÁleZ, G., HERRERA, G., GARCÍA, M. T. \& PEÑA, M., 2001, Biodegradation of phenolic industrial wastewater in a fluidized bed biorreactor with immobilized cells of Pseudomonas putida. Biores. Technol., 80: 137-142. doi: 10.1016/S09608524(01)00076-1.

HERNÁNDEZ, B. S., HIGSON, F. K., KONDRAT, R. \& FOCHT, D. D., 1991, Metabolism and inhibition by Chlorbenzoates in Pseudomonas putida P111. Appl. Environ. Microbiol., 57: 33613366.

HSIEN, T. Y. \& LIN, Y. H., 2005, Biodegradation of phenolic wastewater in a fixed biofilm reactor. Biochem. Eng. J., 27: 95103. doi: 10.1016/j.bej.2005.08.023.

KAR, S., SWAMINATHAN, T. \& BARADARAJAN, A., 1997, Biodegradation of phenol and cresol isomer mixtures by Arthrobacter. World J. Microbiol. Biotechnol., 13: 659-663. doi: 10.1023/A:1018518904730.

KARGI, F. \& EKER, S., 2005, Removal of 2,4-dichlorophenol and toxicity from synthetic wastewater in a rotating perforated tube biofilm reactor. Process Biochem., 40: 2105-2111. doi: 10.1016/j. procbio.2004.07.013.

KAŞIKARA PAZARLIOĞLU, N. \& TELEFONCU, A., 2005, Biodegradation of phenol by Pseudomonas putida immobilized on activated pumice particles. Process Biochem., 40: 1807-1814. doi: 10.1016/j.procbio.2004.06.043.

KOROL, S., ORSINGHER, M., SANTINI, P.; MORETTON, J. \& D'AQUINO, M., 1989, Biodegradation of phenolic compounds II. Effects of inoculum, xenobiotic concentration and adaptation on Acinetobacter and Pseudomonas phenol degradation. Rev. Lat-amer. Microbiol., 31:117-120.

KROONEMAN, J., SLIEKERS, O., TERESA, M., GOMES, P., FORNEY, L. J. \& GOTTSCHALL, J. C., 2000, Characterization of 3-chlorobenzoate degrading aerobic bacteria isolated under various environmental conditions. FEMS Microbiol. Ecol., 32:53-59. doi: 10.1111/j.1574-6941.2000.tb00698.x. 
PALLERLA, S. \& CHAMBERS, R. P., 1998, Reactor development for biodegradation of pentachlorophenol. Catal. Today, 40: 103111. doi:10.1016/S0920-5861(97)00128-4.

PAVlÚ, L., VOSÁHLOVÁ, H., PROUZA, M., DEMNEROVÁ, K. \& BRENNER, V., 1999, Characterization of chlorobenzoate degraders isolated from polychlorinated biphenyl-contaminated soil and sediment in the Czech Republic. J. Applied Microbiol., 87: 381-386. doi: 10.1046/j.1365-2672.1999.00830.x.

PERRON, N. \& WELANDER, U., 2004, Degradation of phenol and cresol at low temperatures using a suspended-carrier biofilm process. Chemosphere, 55: 45-50. doi: 10.1016/j. chemosphere.2003.10.037.

QUAN, X., SHI, H., ZHANG, Y., WANG, J. \& QIAN, Y., 2003, Biodegradation of 2,4-dichlorophenol in an air-lift honeycomblike ceramic reactor. Process Biochem., 38: 1545-1551. doi: 10.1016/S0032-9592(03)00046-3.

QURESHI, F. M., BADAR, U. \& AHMED, N., 2001, Biosorption of copper by a bacterial biofilm on a flexible polyvinyl chloride conduit. Appl. Environ. Microbiol., 67: 4349-4352. doi: 10.1128/ AEM.67.9.4349-4352.2001.

SÁ, C. S. A. \& BOAVENTURA, R. A. R., 2001, Biodegradation of phenol by Pseudomonas putida DSM 548 in a trickling bed reactor. Biochem. Eng., J. 9: 211-219. doi: 10.1016/S1369703X(01)00149-8.
SAINI, H. S., CHADHA, B. S., BHASKAR, S., SINGH, S., KUMAR, R. \& MAHAJAN, M., 1998, Biodegradation of chlorobenzoates by Actinomycetes. World J Microbiol. Biotechnol., 14: 785-786. doi: 10.1023/A:1008852503617.

SONG, B., PALlERONI, N. J. \& HÄGGBLOM, M. M., 2000, Isolation and characterization of diverse halobenzoate-degrading denitrifying bacteria from soils and sediments. Appl. Environ. Microbiol., 66: 3446-3453. doi: 10.1128/AEM.66.8.34463453.2000.

SPRINGAEL, D., PEYS, K., RYNGAERT, A., VAN ROY, S., HOOYBERGHS, L., RAVATN, R., HEYNDRICKX, M., VAN DER MEER, J. R., VANDECASTEELE, C., MERGEAY, M. \& DIELS, L., 2002, Community shifts in a seeded 3-chlorobenzoate degrading membrane biofilm reactor: indications for involvement of in situ horizontal transfer of the clc-element from inoculum to contaminant bacteria. Environ. Microbiol., 4: 70-80. doi: 10.1046/j.1462-2920.2002.00267.x.

WILSON, G. J., KHODADOUST, A. P., SUIDAN, M. T. \& BRENNER, R. C., 1997, Anaerobic/aerobic biodegradation of pentachlorophenol using GAC fluidized bed reactors: optimization of the empty bed contact time. Wat. Sci. Tech., 36: 107-115. doi: 10.1016/S0273-1223(97)00513-1. 
